\title{
Towards a European public sphere? A comparative study of the Facebook activities of Danish and Spanish members of the European Parliament
}

\author{
Lidia Valera-Ordaz; Mads P. Sørensen
}

How to quote this article:

Valera-Ordaz, Lidia; Sørensen, Mads P. (2019). "Towards a European public sphere? A comparative study of the Facebook activities of Danish and Spanish members of the European Parliament". El profesional de la información, v. 28, n. 6, e280611.

https://doi.org/10.3145/epi.2019.nov.11

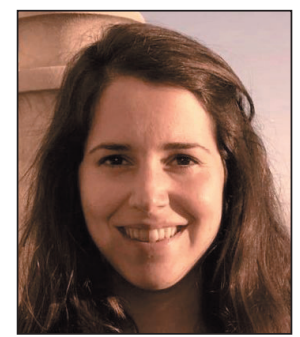

\author{
Lidia Valera-Ordaz $\square$ \\ https://orcid.org/0000-0002-1085-980X \\ Universidad de Valencia \\ Fac. de Filología, Traducción y Com. \\ Dpto. de Teoría de los Lenguajes y \\ Ciencias de la Comunicación \\ Av. de Blasco Ibáñez, 32 \\ 46010 Valencia, Spain \\ lidia.valera@uv.es
}

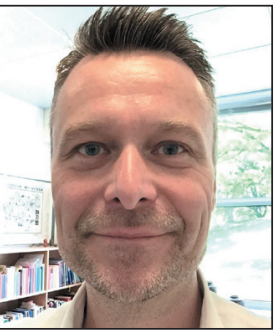

Manuscript received on 20 2 th March 2019 Accepted on $25^{\text {th }}$ October 2019

\begin{abstract}
This comparative study examines the everyday Facebook activities of all Danish and Spanish members of the European Parliament (MEPs), and the extent to which there is a real political conversation between citizens and European representatives. Through content analysis, it analyzes the Facebook practices of a significantly under-studied population (MEPs) during a non-campaign period (January 15 to February 15, 2017) while most of recent research has overwhelmingly focused on campaign periods. The results show that both Danish and Spanish MEPs are generously present and active on Facebook, but that they are less popular than their national counterparts. The study shows that Danish MEPs use Facebook in a clearly more dialogue-oriented way than their Spanish colleagues. Their updates often lead to conversations between followers, and they frequently take part in these political discussions, while Spanish MEPs tend to limit their Facebook practices to content publication, avoiding citizen conversation.
\end{abstract}

\section{Keywords}

Facebook; Social media; Political communication; Political conversation; Public sphere; European Parliament; Political representatives; Citizens; Dialogue; Interactivity; Democratic deficit; Members of Parliament; MEP; Politicians; Denmark; Spain.

\section{Introduction}

The European Union (EU) is facing an unprecedented crisis after 51.9 percent of the British electorate in June 2016 voted for the United Kingdom's official exit from the EU. The Brexit crisis has shown that a huge number of British citizens do not feel represented by the European project, and it has underlined how difficult it is to maintain citizen support for the European political integration project.

\section{Acknowledgments}

This study has required a significant amount of manual work in collecting data, counting likes and comments, and coding posts. The authors would like to thank Matias Engdal Christensen for invaluable help with these tasks as well as for his help with the tables and figures.

Funding

This research has benefited from postdoctoral grant Apost2016, awarded by Generalitat Valenciana to Lidia Valera-Ordaz. 
But the lack of political legitimacy of the EU is not a new problem; it has been discussed for decades both in the news media and in academia (Føllesdal; Hix, 2006). According to its standard definition, the discourse on the "democratic deficit" generally includes critiques against the weakness of the European Parliament, the structural remoteness of European political elites from constituents, the bureaucratic nature of the European decision-making process, and the scant power of member states' legislatives to control decisions made by the European Commission and the European Council (Weiler; Haltern; Mayer, 1995). This democratic deficit manifests itself, for example, in the decreasing turnout to European elections, despite the gradual increase in the formal powers of the European Parliament. Even the recent 50 percent turnout in the 2019 election, which constitutes the first increase in the last 20 years, is significantly lower than the regular turnout registered in national elections of member states (European Parliament, 2019).

Along with this, it has been a common place among communication scholars to emphasize that there is also a "communication gap" between EU institutions and the citizenry, due to a rather shallow media coverage of European issues by journalists (Seoane-Pérez, 2013, p. 153). In sum, there is a "lack of interest in and knowledge of the European Union" among most European citizens (Vesnic-Alejuvic, 2013, p. 11).

In this context, digital technologies seem to be essential tools for strengthening bonds between politicians and citizens. Social media, such as Facebook and Twitter, exhibit an interactive potential, allowing citizens to establish direct communication with political representatives (Lilleker; Koc-Mihalska, 2014; Robertson; Vatrapu; Medina, 2010). Their relevance lies in the capacity to host conversations between citizens and MEPs, helping to reduce the structural distance between them and serving as a first ground for a more vibrant European public sphere. Political conversation has also been found to produce positive outcomes for democracy, such as increasing political knowledge and civic engagement (Shah, 2016, p. 15).

To use Facebook for political conversations also seem to be an idea that many Europeans support. Thus, an online survey shows that Europeans from 16 member states agree,

"that Facebook is a suitable space for interactive political communication" (Vesnic-Alejuvic, 2012, p. 469).

Moreover, even though Twitter is generally preferred by campaign managers at the EU level due to its high popularity among journalists, bloggers, experts, and political "junkies", most individual MEPs are more present on Facebook than on Twitter (Vesnic-Alejuvic, 2013, p. 30).

This is no surprise since Facebook is the most popular social medium among the general population, also compared to Twitter. In Europe, there were 659 million Internet users during the observation period of our study (2017), and 343 million of these were Facebook users (Internet World Stats, 2017). During the same period, Facebook had a penetration rate of $64.1 \%$ in Denmark, and one of $49.5 \%$ in Spain (Internet World Stats, 2017).

Several studies support the centrality of Facebook as the dominant social medium among the general population (CIS, 2016; AIMC, 2017). For example, in Spain, 87 percent of Internet users declare to use Facebook, while only 48 percent use Twitter (AIMC, 2017). In Denmark, 66 percent of the population aged 16-89 used Facebook at least once a week in 2017, whereas only 5 percent used Twitter (The Danish Agency for Culture and Palaces, 2017, p. 21).

The dominance of Facebook is not only related to its popularity among the general population but also to its digital architecture. A recent study shows that this platform was the most attractive for campaign managers during the 2016 U.S. Election (compared to Twitter, Instagram and Snapchat) due to its functionality of hyperlinking, which allowed to derive traffic to other websites, its nonrestrictive rules regarding video length, and the open network structure behind Facebook public pages (Bossetta, 2018, p. 491).

So far, research on Facebook in the institutional context of the EU has been significantly scarce (see, for example, Sampietro; Valera-Ordaz, 2015; Vesnic-Alujevic, 2013; 2016), since researchers have overwhelmingly focused on national contexts. Moreover, despite Facebook's relevance among the general population, Twitter has captured the most attention among scholars, probably due to its above-mentioned popularity among journalists and political junkies (see, for example, Alonso-Muñoz; Casero-Ripollés, 2018; Bouza-García; Tuñón-Navarro, 2018; López-García et al., 2015).

In this sense, Instagram is recently attracting attention among scholars. So far, studies analyzing how political actors use this social platform show that it serves for broadcasting purposes rather than for mobilization, and that political parties use it for disseminating information that followers are not expected to respond to (Filiminov; Russmann; Svensson, 2016). This allows campaigns to control the image of their candidates via uploading polished content (Bossetta, 2018). Hence, a recent study found that despite its interactive potential, Swedish politicians using Instagram are basically "preoccupied with the branding of their public persona" (Ekman; Widholm 2017, p. 15) and avoid public interaction.

In addition, it is worth noticing that elections and campaign periods have attracted most academic attention in and outside the EU (see, for example, Camaj; Santana, 2015; López-García, 2016; López-Meri; Marcos-García; Casero-Ripollés, 2017; Robertson; Vatrapu; Medina, 2010; Sweetser; Lariscy, 2008), while the regular everyday activities of political representatives on social media have been rather unattended, with some exceptions (Alonso-Muñoz; Casero-Ripollés, 2018; Sørensen, 2016a; Larsson; Kalsnes, 2014). 
Regarding the institutional context of the EU, a recent study shows that political parties used Facebook more as a means for advertising rather than for dialogue or for facilitating political discussions during the last two European Parliament elections (2009 and 2014). Political organizations mainly used it to inform followers about campaign events, but they rarely participated in citizen conversations (Vesnic-Alujevic, 2016). In sum, there was no real interaction between the political parties and their Facebook followers in 2009 or 2014.

Similar results have been observed at the national level in a number of countries. Many studies have analyzed politicians' and citizens' engagement on Facebook, both in European countries (see, for example, Di-Bonito, 2014; Gámir-Ríos, 2016; Larsson; Kalsnes, 2014; Sørensen, 2016a; Valera-Ordaz, 2017; 2019) and in other contexts (see, for example, Camaj; Santana, 2015; Muñiz et al., 2016; 2019; Ross; Fountaine; Corrie, 2015). Especially prevalent have been approaches using deliberative theory to assess the quality of conversations (Wright, 2011). Most of these studies have reported a lack of deliberative quality of political Facebook conversations inasmuch as they are generally superficial, not rationally oriented, and they feature a low level of interaction (Fernandes et al., 2010; Sweetser; Lariscy, 2008).

Thus, the role of political actors in their own Facebook pages is generally limited to content moderation and agenda-setting (Camaj; Santana, 2015), and they only rarely participate in dialogues with citizens (Valera-Ordaz, 2017). Still, some studies analyzing politicians' regular Facebook activities in non-campaign periods show that there is, indeed, a good deal of interaction between citizens and political representatives, at least in countries with a strong tradition of political participation, such as Sweden, Norway and Denmark (Larsson; Kalsnes, 2014; Sørensen, 2016a).

Given the scarce knowledge on how European representatives engage with social media and if (and how) they interact with citizens, the present study aims to contribute to the existing literature by

1) quantitatively mapping MEPs' usual social media practices;

2) focusing on the dominant social network worldwide (Facebook);

3) offering a comparative approach that looks at MEPs' regular Facebook practices from two countries with significantly different political cultures and patterns of political participation (Spain and Denmark).

The study intentionally chooses to focus on a non-campaign period in order to avoid any bias derived from special events, and in order to capture MEP's real everyday Facebook practices. Exploring these questions will help us assess to what extent social media can serve as a platform for a more vibrant European public sphere. More specifically, this article seeks to answer the following research questions:

RQ1. How present are Spanish and Danish MEPs on Facebook, and what do their everyday Facebook practices look like (in terms of content publication, number of followers, and likes)?

RQ2. Does Facebook serve as a platform for political conversations between MEPs and citizens? Do MEPs comment on their own political posts and engage in real conversations with citizens?

RQ3. Are there any remarkable differences between the Facebook practices of Spanish and Danish MEPs -and do the differences reflect different political cultures?

\section{Methods}

\subsection{Sample selection}

Despite the increasing power of the European Parliament in comparison with national parliaments, the Facebook practices of the members of the European Parliament (MEPs) are significantly understudied in comparison with national political elites. Therefore, we have chosen to focus on this group in the present study. More specifically, our sample consists of 66 MEPs, 54 elected in Spain, and 12 in Denmark. We chose to focus on Denmark and Spain because these two countries embody two significantly different political cultures, which - we hypothesize - will give us a broad picture of the use of Facebook for political conversations among MEPs.

On the one hand, Denmark, together with the rest of Scandinavia, exhibits a strong participatory culture that manifests itself in a high electoral participation, frequent contact with political actors, usual collaboration with different political and civic associations, etc. (Teorell; Torcal; Montero, 2007). Moreover, deliberative democratic ideals have historically played a prominent role in both politicians' and the public's understanding of democracy ${ }^{1}$. The idea that political conversations are key to a well-functioning public sphere is generally accepted in Denmark, and previous studies show that Danish MPs interact with citizens through social media, and are involved in conversations with their Facebook followers (Sørensen, 2016a), especially compared to colleagues in other countries (Muñiz et al., 2016; Valera-Ordaz, 2017).

In contrast to Denmark, political participation in Spain has historically been limited due to a lengthy dictatorship and a late transition to democracy (Delgado-Sotillos; López-Nieto, 2008; Torcal; Montero; Teorell, 2006). Political cynicism and mistrust towards political elites are widespread among the Spanish population, as indicated by the Sociological Research Centre. For example, during the time frame of our study, $23.4 \%$ of the Spanish population declared that politics and political parties were a major problem in Spain (CIS, 2017).

Moreover, Spanish political parties dominate political life and parliamentary activities through strong party discipline, so 
that individual politicians rarely relate directly with the citizenry. Their activities are centralized and coordinated by the organizations to which they belong. In addition, previous studies have repeatedly shown that Spanish political actors use Facebook mainly for content publication and marketing purposes and that they rarely engage in real conversations with citizens (Dader, 2009; Túñez; Sixto, 2011; Valera-Ordaz, 2017).

Denmark and Spain also feature different media systems, according to the typology developed by Hallin and Mancini (2004). While Spain corresponds to the polarized pluralistic media system, where the news media have historically been oriented towards political elites, Denmark is included in the democratic corporatist model, characterized by a high newspaper circulation among the population. In other words, the differences in their respective democratization processes and political cultures are also reflected in the structure of their media markets, their patterns of political parallelism and their unequal levels of journalistic professionalization.

Hence, the two countries can thus be seen as examples of a "most likely" (Denmark) and a "least likely" (Spain) case for individual politicians' interaction with citizens on Facebook (Flyvbjerg, 2006). By covering these two opposite cases, we expect to obtain reliable knowledge on the span in how MEPs are using social media to interact with citizens.

\subsection{Time frame}

We have deliberately placed the monitored period outside of an election campaign period to examine the normal social media practices of the MEPs as well as their everyday engagement in Facebook conversations. By monitoring a period outside of an election campaign, we aim to get an accurate picture of MEPs' regular activities and to avoid any possible bias derived from special events and campaign activities. Elections always motivate political actors to use digital technologies (and any other tools at their disposal) to attract and mobilize the electorate. Therefore, it is necessary to study a period outside an election campaign to get an accurate picture of the day-to-day interaction between MEPs and citizens.

In deciding the period of observation, we took into account that there was regular parliamentary work going on, so that MEPs were actively involved in plenary sessions. The period we selected ranges from January $15^{\text {th }}$ to February $15^{\text {th }} 2017$, both days included. During this month, nine plenary sessions took place, on the following dates: January $16^{\text {th }}, 17^{\text {th }}, 18^{\text {th }}$ and $19^{\text {th }}$, and February $1^{\text {st }}, 2^{\text {nd }}, 13^{\text {th }}, 14^{\text {th }}$ and $15^{\text {th }}$. This is a moderately intense rate for the European Parliament, given that it celebrated around six plenary sessions per month during 2017.

\subsection{Data collection}

The data collection was completed by the end of the period of the study (February 15, 2017), and it was carried out partly manually and partly using the tool NCapture, offered by the software NVivo 11. First, background variables from each MEP were manually collected from his/her official EU webpage (MEP's name, political party, party membership, political group in the EP, country, gender and age).

Table 1. Data collection of MEPs Facebook posts and citizen comments.

\begin{tabular}{|l|c|c|c|c|}
\hline & Public Facebook page & Private Facebook page & No Facebook page & Total \\
\hline Number of MEPs & 37 & 17 & 12 & 66 \\
\hline Data collection as & CSV file & PDF file & & \\
\hline
\end{tabular}

Second, NCapture/NVivo 11 was used to collect all MEPs' Facebook posts and the citizen comments made in response. This application allowed us to directly store the data collected from the MEPs Facebook pages in a database like a comma-separated values (CSV) file. However, that was only the case when the MEPs' Facebook pages were public. For MEPs, whose Facebook pages were private, we had to store the content published during the monitored period as portable document format (PDF) files, and subsequently manually count them (see Table 1).

\subsection{Variables}

In order to shed light on our research questions, we used the following variables. First, a number of background variables describing each MEP: name, political party, political group in the European Parliament, country of election, gender and age.

Second, regarding MEPs' Facebook presence and popularity, we analyzed the following questions:

1) existence of a Facebook page;

2) account's link from the European Parliament webpage,

3) nature of the Facebook page (private vs. public);

4) number of followers;

5) number of posts;

6) number of posts discussing public issues;

7) number of likes;

8) number of comments.

Finally, in order to explore our second research question, i.e. the existence of political conversations between European representatives and citizens, we draw on literature about democratic conversations (Schudson, 1997), and the public 
sphere (Dewey, 1991; Habermas, 1974; 1989). Building on this literature and Sørensen (2016a), we defined a political conversation as a communicative interaction between two or more people on matters of public interest. We conceived public interest issues in a broad sense, as those that actually affect or can potentially affect the life of European citizens in any possible way.

In operationalizing the concept of political conversation, emphasis was put on two things:

1) the conversation had to be about issues of public interest; and

2) there had to be mutual commitment/responsiveness.

Accordingly, all MEPs Facebook posts during the monitored period ( $n=1428$ ) were first coded as either of public interest $(n=1370)$ or private $(n=58)$. All the posts related to the political domain in a broad sense were coded as public, while only personal statements related to the private sphere of MEPs, which therefore were of no or very limited interest for the citizenry, were coded as private, following previous research (Sørensen, 2016a). For example, posts related to the families of MEPs were treated as private.

Hereafter, the public posts were coded for conversation activity. Public posts, where the MEP and/or the citizens reentered the Facebook thread at least once to reply to a comment to their own post/comment, were coded as containing conversation. The study thus operates with a distinction between:

a) Facebook threads where MEPs and/or citizens engage in conversations by reacting to comments made by others to their own posts/comments, and

b) threads were MEPs and/or citizens simply post opinions without communicative interaction.

\section{Findings}

Findings are presented in the following way. First, the presence, the activities, and the popularity of Danish and Spanish MEPs on Facebook are discussed. Second, we examine the type of communication that takes place on Facebook, that is, the number of comments made by the MEPs in their own political posts, the existence of conversations between political representatives and citizens, and between citizens themselves. Since the study is comparative in nature, differences between Spanish and Danish MEPs are discussed throughout the section.

\subsection{MEPs presence on Facebook}

As shown in Table 2, Danish MEPs are significantly more present on Facebook than Spanish MEPs. While all Danish representatives in the European Parliament have a Facebook account, only 42 out of 54 Spanish representatives have one (78\%). In this sense, Danish MEPs' presence on Facebook confirms previous findings of Scandinavian politicians' extensive use of social media (Larsson; Kalsnes, 2014; Sørensen, 2016a), which might be the result of a strong culture of political participation.

If we look at Spanish MEPs' presence on Facebook by political party (Figure 1), left-wing parties (Podemos, Izquierda Unida and PSOE) generally use Facebook more than right-wing organizations. Right-wing parties like PP and Ciudadanos are the groups using Facebook less often, together with UPyD and regional parties Alternativa Galega and EH Bildu. For example, only 9 out of 16 of the $P P$ representatives have a Facebook account, whereas all representatives from Izquierda Unida, Podemos and 11 out of 13 of the PSOE are present on Facebook, which further testify to the importance of digital politics for Podemos (Casero-Ripollés; Feenstra; Tormey, 2016). In other words, the more leftist the party, the more massive the presence of Spanish MEPs is on Facebook. These results are in line with previous findings suggesting that leftist parties have a stronger inclination to use social media (Cardenal, 2013; Sudulich, 2013).

In terms of the center-periphery cleavage, most of the regional nationalist parties have Facebook presence, such as the Catalan parties ERC, $U D C$, and $C D C$. Other regional political organizations, however, show lower presence on Facebook (Alternativa Galega de Esquerda en Europa, PNV and Bildu).

Table 2. Danish and Spanish MEPs presence on Facebook

\begin{tabular}{|l|c|c|c|}
\cline { 2 - 4 } \multicolumn{1}{c|}{} & Facebook account & No Facebook account & Total \\
\hline Danish MEPs & 12 & 0 & 12 \\
\hline Spanish MEPs & 42 & 12 & 54 \\
\hline
\end{tabular}

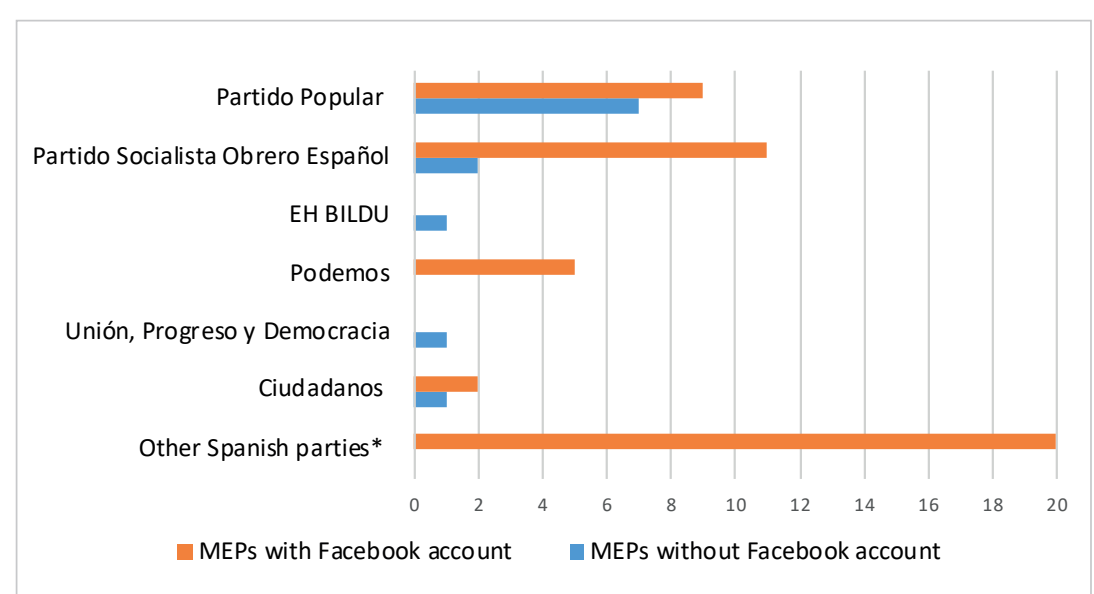

Figure 1. Facebook presence of Spanish MEPs by political party 
The same pattern emerges if we look at MEPs' Facebook presence by political group in the European Parliament (Figure 2), given that most of the analyzed sample were Spanish MEPs. Political groups that exhibit left-wing ideological orientations, such as the Group of the Greens and the Confederal Group of European United Left and the Group of the Progressive Alliance of Socialists and Democrats, are better represented on Facebook than the Group of European People's Party or the Group of the Alliance of Liberals and Democrats for Europe.

\subsection{MEPs activities on Facebook}

Spanish MEPs are more active than their Danish colleagues are when it comes to publishing content of public interest, as shown in Table 3. More specificaIly, each Danish representative posted on average 18 posts during the studied month, while each Spanish MEP used his or her Facebook profile to publish 20 updates during the same period.

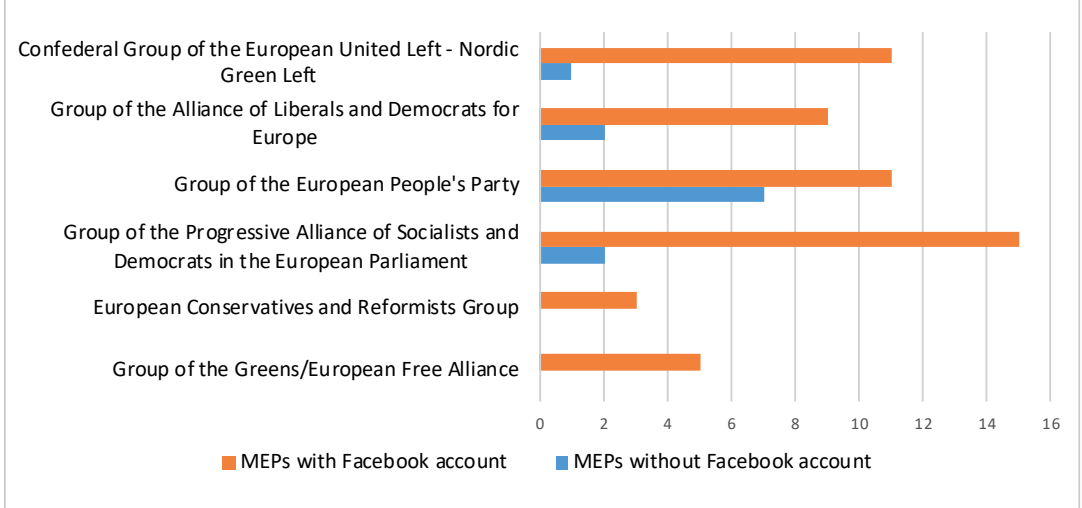

Figure 2. Facebook presence of Spanish and Danish MEPs (shown by their European Parliament groups)

Further, we examined if the MEPs' posting behavior also varied by political orientation (Table 4). We did that through the cross tabulation of the mean number of public posts of Danish and Spanish MEPs by the ideological orientation of each MEP, using the broad categories left, right and independent (for MEPs who did not belong to a specific political party in the monitored period or won their seat as independent candidates).

Our results seem to highlight important differences across the left-right divide, since MEPs who belong to leftist political parties published 26 posts of public interest on average in the monitored period, whereas their colleagues on the right side posted only 11 updates during the same period. Moreover, these differences are particularly important in the Spanish case (Table 4), since Danish MEPs publication rates on Facebook, as we will see, exhibit less variation. In other words, these differences need to be interpreted in light of the unequal sample sizes, since they are influenced by the bigger presence of Spanish representatives.

If we look closer at the figures, there is great variance between the Spanish MEPs, as shown in Figure 3. While some Spanish MEPs were very active (24 percent made more than 30 updates, and 17 percent published between 16 and 30 Facebook posts), 17 percent did not publish any updates at all, despite having a Facebook page, and 22 percent did not have a Facebook account. In sum, Spanish MEPs' use of Facebook presents a lot of variance, ranging from very engaged politicians, who exhibited high publication rates, to other representatives, who - despite having a Facebook account - did not use it at all.

In contrast to this pattern, the use of Facebook was significantly more stable across Danish MEPs since all Danish representatives published updates during the observation period. They were not as active as some of their Spanish peers, but all of them used Facebook regularly. Specifically, half of them published between 6 and 15 updates during the period of the study, and 33 percent of them updated their profiles between 16 and 30 times. Only 8 percent of them published over 30 posts, though. In sum, Danish MEPs exhibited a more stable and generalized use of Facebook, whereas Spanish MEPs showed a huge range of variety when it came to their Facebook use. Obviously, the larger sample size in the Spanish case can be seen as a reason of variance, but national differences persist through our results, as we will see throughout the paper.

\subsection{MEPs popularity on Facebook}

What about MEPs popularity on Facebook in terms of followers and likes? That is, how many people follow on average MEPs activities on Facebook? Table 5 shows the total number of followers of Danish and Spanish MEPs by February 15 , 
2017 and the mean number of them (that is, the total number of followers attracted by all MEPs of each nationality divided by the number of MEPs of each country). Results indicate that Danish MEPs are significantly more popular on Facebook than Spanish MEPs, since they attract more than twice as many followers on average. These differences are very significant, given that Spain has a population of more than 46 million people, and Denmark less than 6 million.

There is, however, a great deal of variance, as shown by the scatter plots of Danish and Spanish MEPs' number of followers (Figures 4 and 5). While a few representatives are followed by more than 20,000 people, most of them have less than 5,000 followers. For example, three out of the four most followed MEPs are Spanish (Elena Valenciano: 36,278, Miguel Urbán: 25,664 and Tania González: 22,755), while only one is Danish (Jens Rohde: 31,464 followers). Still, despite these outliers, most of the Spanish MEPs do not attract more than 5,000 to 10,000 followers, as shown by the concentration of dots below the axis of 5,000 and 10,000 (Figure 5), while most Danish MEPs attract more than 10,000 followers (Figure 4).

When it comes to how many likes they receive to their updates, Danish MEPs are also significantly more popular than the Spanish MEPs. The reason for this is probably connected to their higher visibility (Table 6). Concretely, Danish MEPs' Facebook posts attracted 42,102 likes, while Spanish MEPs received 53,180. If we divide the total number of likes by the total number of posts published by Danish and Spanish MEPs, results confirm the bigger popularity of Danish MEPs. Each of their updates received on average 199 likes, while an update by a Spanish representative on average only got 48 likes.

\subsection{One-way communication or dialo- gue?}

Besides MEPs' presence and popularity on $\mathrm{Fa}$ cebook, it is worth analyzing to what extent this social platform is used for establishing real dialogues between European representatives and constituents, or between citizen themselves. Table 7 presents the number of comments made by MEPs in their own Facebook posts, and Figure 6 illustrates it. Tables 8 and 9 offer complementary information about MEPs' comments in their own posts by their ideology, both in absolute and relative terms.

Findings confirm that Spanish MEPs are clearly more oriented towards writing updates, as previously described, but that they rarely reenter their publications to add additional

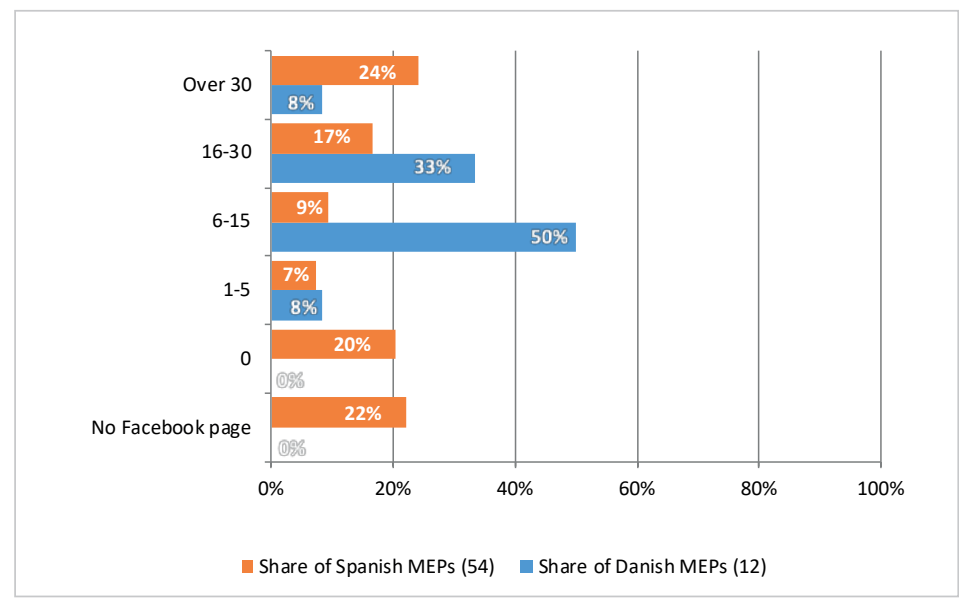

Figure 3. Percentage of Spanish vs. Danish MEPs by number of published posts

Table 5. Danish and Spanish MEPs' followers on Facebook

\begin{tabular}{|l|c|c|}
\hline & Total $\mathbf{n}^{\circ}$ of followers & Mean $\mathbf{n}^{\circ}$ of followers \\
\hline Danish MEPs (12) & 156,768 & 13,064 \\
\hline Spanish MEPs (54) & 276,229 & 5,115 \\
\hline
\end{tabular}

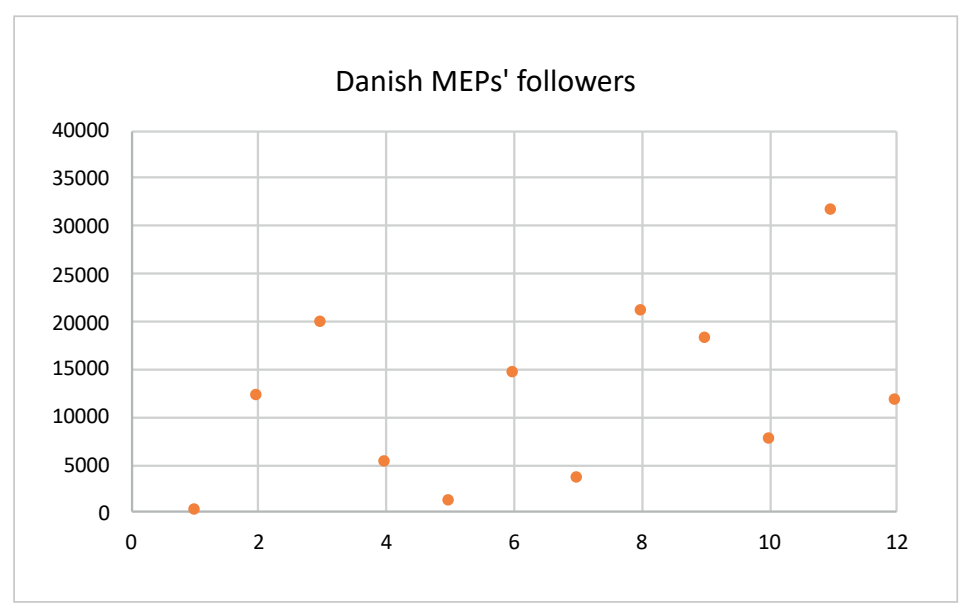

Figure 4. Scatter plot for Danish MEPs number of followers

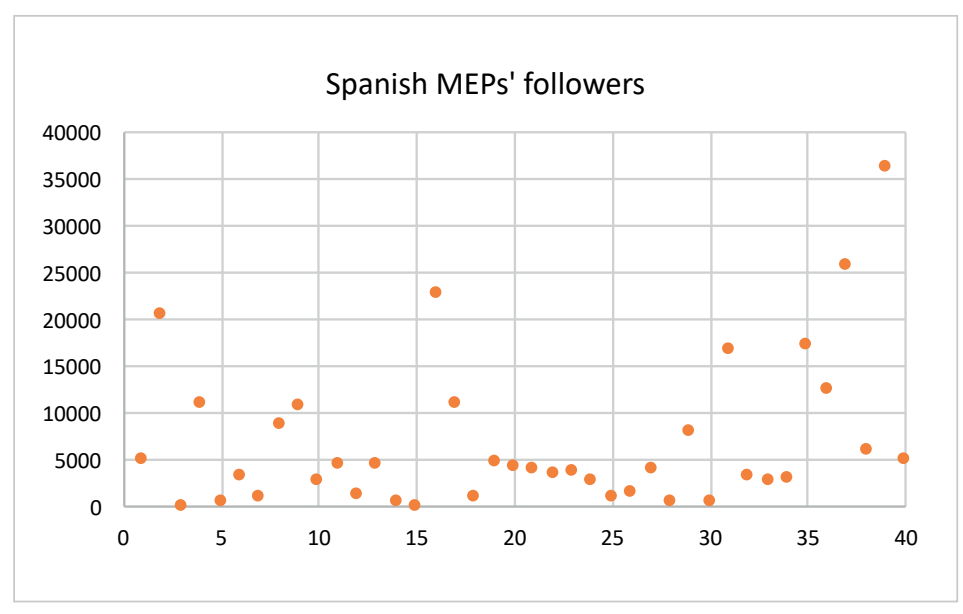

Figure 5. Scatter plot for Spanish MEPs number of followers

Table 6. Danish and Spanish MEPs' likes on Facebook

\begin{tabular}{|l|c|c|}
\hline & Total number of likes & $\begin{array}{c}\text { Mean number of likes } \\
\text { per post }\end{array}$ \\
\hline Danish MEPs (12) & 42,102 & 199 \\
\hline Spanish MEPs (54) & 53,180 & 48 \\
\hline
\end{tabular}


Table 7. Number of comments from MEPs in own political posts

\begin{tabular}{|l|c|c|c|}
\hline & No of posts & $\begin{array}{c}N^{\circ} \text { of MEPs comments in } \\
\text { their own posts }\end{array}$ & $\begin{array}{c}\text { Mean n' of MEPs com- } \\
\text { ments per post }\end{array}$ \\
\hline Danish MEPs (12) & 212 & 292 & 1.38 \\
\hline Spanish MEPs (54) & 1101 & 157 & 0.14 \\
\hline
\end{tabular}

information or to answer questions posted by citizens (Table VII). Altogether, Danish MEPs published 292 comments in their own 212 updates, while Spanish representatives only did so 157 times in more than a thousand posts. In other words, Spanish MEPs rarely engage in conversations with citizens in comparison with their Northern colleagues. On average, each Danish MEP re-entered his or her own updates 24.33 times, whereas this only happened 2.90 times for each Spanish MEP.

Indeed, most of the Spanish representatives never re-entered their own posts to post a comment (26 out of the 42 who had a Facebook account), while this was only the case for two Danish MEPs. Figure 6 clearly confirms how Danish MEPs are generally more inclined towards interaction, ranging from the hyperactive case of Jens Rohde, who published 145 comments to his posts to more moderately active answering behaviors.

Are there differences in MEPs' inclination towards dialogue if we look at their political orientation? Do MEPs, who belong to left-wing political parties re-enter their own posts more often to publish a comment than those who belong to right-wing parties? Not if we look at the Spanish MEPs. On average, Spanish MEPs from either left or right-wing parties re-entered their own updates around 3 times. Table VIII shows bigger differences between the Danish MEPs. However, given the small number of observations -and the presence of the very active MEP Jens Rohde in the left group- we cannot conclude anything about Danish right or left wing parties' inclination towards dialogue, based on this

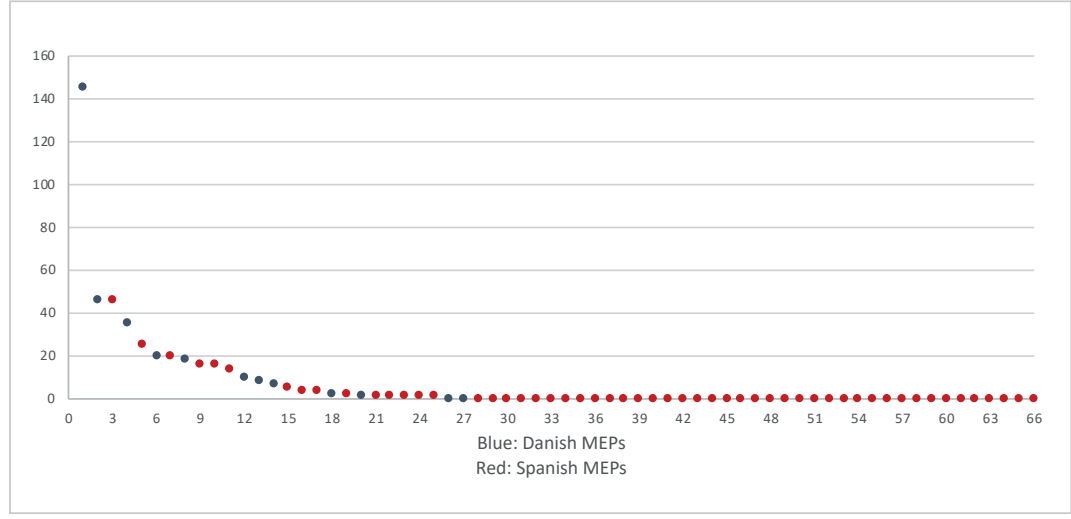

Figure 6. Number of MEPs' comments in their own posts

Table 8. № of comments from MEPs in own political posts by ideology

\begin{tabular}{|l|c|c|c|c|}
\cline { 2 - 5 } \multicolumn{1}{c|}{} & Left & Right & Independent & Total \\
\hline Danish MEPs & 260 & 30 & 2 & 292 \\
\hline Spanish MEPs & 85 & 71 & 1 & 157 \\
\hline Total & 345 & 101 & 3 & 449 \\
\hline
\end{tabular}

Table 9. Mean no of MEP comments per MEP in own political posts by ideology

\begin{tabular}{|l|c|c|c|c|}
\cline { 2 - 5 } \multicolumn{1}{c|}{} & Left & Right & Independent & Total \\
\hline Danish MEPs & 37.14 & 7.50 & 2.0 & 24.33 \\
\hline Spanish MEPs & 2.93 & 3.08 & 0.5 & 2.90 \\
\hline Total & 9.58 & 3.74 & 1.0 & 8.31 \\
\hline
\end{tabular}

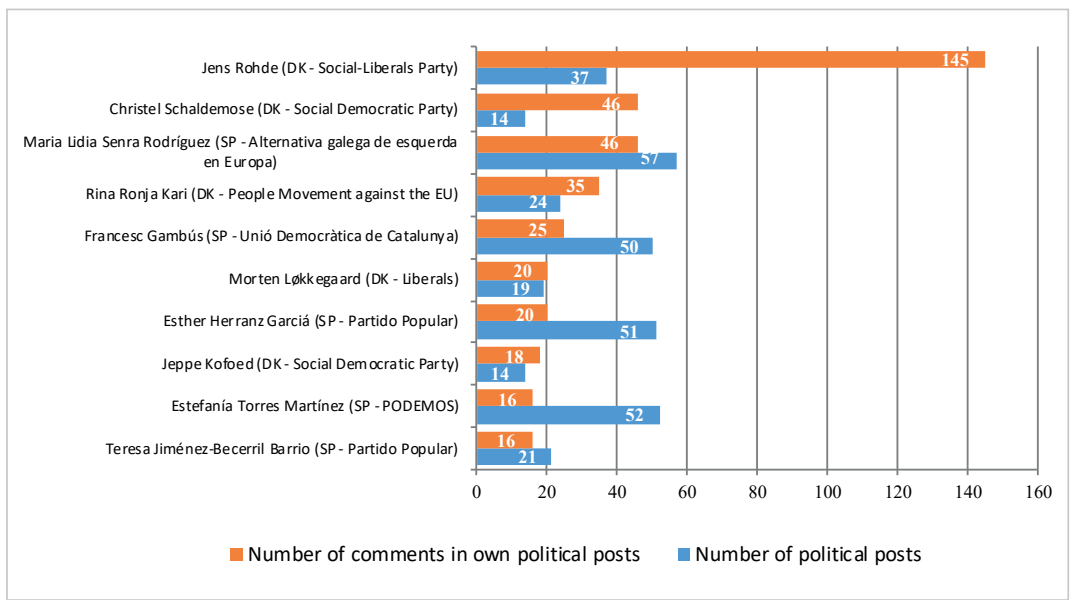

Figure 7. The 10 most answering MEPs

study. A previous study of all Danish MPs' activities on Facebook (Sørensen, 2016a) showed differences between Danish parties, but these differences were not distributed along the left-right divide. There were right and left wing parties among the most dialogue-oriented parties as well as among the least dialogue-oriented.

Figure 7 presents the ten most answering MEPs: five of them were Danish and five were Spanish. It shows two important findings:

1) that Jens Rohde is clearly an outlier, since he engages in conversations much more often and systematically than any other MEP (Danish or Spanish), and 
2) that Facebook indeed is used for communicative interaction between MEPs and citizens, also in the Spanish case. MEPs such as Christel Schaldemose, Maria Lidia Serna Rodríguez, Francesc Gambús, or Rina Ronja Kari all seems interested in establishing a dialogue with people commenting on their Facebook pages.

This means that Facebook is used by at least a minority of European political representatives to hold conversations with citizens and engage in real debates with them.

Table 10 shows the number of posts that contain conversations, defined as those where either the MEP or the citizen (or both) reenters the Facebook thread to reply to a comment made in response to their previous comment. Table 11 offers more detailed information on the nature of those conversations.

Table 11. Type of conversations in Danish and Spanish MEPs' Facebook posts

\begin{tabular}{|l|c|c|c|}
\cline { 2 - 4 } \multicolumn{1}{c|}{} & $\begin{array}{c}\text { Total } \mathbf{n}^{\circ} \text { of posts contai- } \\
\text { ning conversations }\end{array}$ & $\begin{array}{c}\mathbf{N}^{\circ} \text { of posts containing } \\
\text { conversations between } \\
\text { MEP and citizens }\end{array}$ & $\begin{array}{c}\text { No of posts containing } \\
\text { conversations between } \\
\text { citizens } \\
\text { both types of conversa- } \\
\text { tion (MEP-citizen and } \\
\text { citizen-citizen) }\end{array}$ \\
\hline Danish MEPs (12) & 124 & $33(27 \%)$ & $37(30 \%)$ \\
\hline Spanish MEPs (54) & 137 & $63(46 \%)$ & $63(46 \%)$ \\
\hline Total & 261 & 96 & 100 \\
\hline
\end{tabular}

If we look at conversation activities in the posts made by the MEPs, the same national differences emerge. While 58.5 percent of the Facebook posts made by Danish representatives contain conversations (either between MEPs and citizens, between citizens, or both), communicative interaction only takes place in 8 percent of the updates published by Spanish MEPs (Table 11). That means that Danish MEPs are clearly more dialogue-oriented on Facebook than Spanish MEPs, since most of the conversations derived from Danish MEPs' Facebook posts include their direct participation. More specifically, 27 percent of the posts include comments from the MEPs, and 43 percent include their direct participation together with citizens replying to previous comments (Table 11). Danish MEPs participate in 70 percent of the posts containing conversations, while their Spanish colleagues do so in 54 percent. Still, these results need to be interpreted in light of the scant proportion of Spanish MEPs' posts containing conversations.

In order to prove the strength of these national differences, we took the case of the extremely active Danish MEP Jens Rohde out of the calculation ${ }^{3}$. This did not change the result. Also without Jens Rohde, the pattern is clear: Danish MEPs are more dialogue-oriented on Facebook than their Spanish peers are.

This suggests that we are dealing with two different styles of Facebook use, which could reflect two different political cultures. According to the Spanish logic, the MEP publishes updates and offers information to the citizenry, but only rarely engages in conversations. This reflects a political culture where dialogue between political representatives and citizens is rather infrequent, probably because of a weak tradition of political participation, which has historically been limited to elites. For its part, the Danish MEPs' use of Facebook reflects a significantly more dialogue-oriented dynamic, echoing a political culture where conversation between political representatives and constituents is considered key to a well-functioning democracy (Koch, 1991; Teorell; Torcal; Montero, 2007).

\section{Discussion}

This paper has explored the everyday Facebook practices of MEPs from two countries (Spain and Denmark). It has looked at the frequency of political conversations on Facebook during a non-campaign period in order to assess to what extent this social media can facilitate a more vibrant European public sphere. In this section, we discuss our findings in relation to our research questions, before reflecting on their implications in the conclusion. Before doing so, we want to emphasize that both the period of observation and our sampling strategy could have influenced results. Future studies on MEPs' social media behavior -looking at the same or different countries- for a longer period will have to confirm the findings obtained in this study.

Regarding MEPs Facebook presence and regular practices (RQ1), our findings show that all Danish MEPs have a Facebook page, while this is not the case for all Spanish MEPs (12 out of 54 are not on Facebook). Spanish MEPs' presence on Facebook is, interestingly enough, stronger among those elected from left-wing political parties, which is in line with previous research findings that highlight the influence of ideology in political actors' social media use (Sudulich, 2013) and conversation dynamics (Valera-Ordaz, 2019). Moreover, our findings contradict previous research pointing right-wing parties to be more active on social media (Lilleker; Jackson, 2010). 
Moreover, Spanish MEPs are quite active in terms of publishing updates, but a deeper analysis shows a great deal of variance among them, probably as a result of the bigger sample size. For their part, Danish MEPs are not as active as some of the Spanish MEPs, but all of them show similar and stable publication rates during the observation period. Moreover, MEPs who belonged to leftist political parties were generally more active in publishing Facebook updates than those who belonged to right-wing political organization, regardless of their nationalities. Ideology therefore emerged as an important variable associated with Facebook use by MEPs.

In terms of likes and followers, Danish representatives produced greater support and attention among citizens. We should underline that despite its significantly smaller population, Danish MEPs attracted on average more followers, likes and comments than their Spanish colleagues. In this sense, the stronger tradition of participation in Danish political culture (Torcal; Montero; Terell, 2016) manifests itself not only in MEPs' conversations and extensive use of social media, but in citizens' interest in following and communicating with their European representatives.

Still, we need to highlight that individual MEPs on average are clearly less popular on Facebook than their national political parties, which tend to attract more than 50,000 followers (Vesnic-Alujevic, 2016). The same happens if we compare MEPs' popularity with that of members of national parliaments, who attract more followers, both in Denmark (Sørensen, 2016a) and Spain (Valera-Ordaz, 2017). The lower popularity of MEPs is probably related to the structural remoteness of the European Parliament to most European citizens, i.e. the lack of "identification between representatives and represented" (Seoane-Pérez, 2013, p. 12). A socio-psychological distance, which historically has been facilitated by lower media coverage of European politics compared to national politics.

Regarding our question about MEPs' inclination towards dialogue (RQ2), the answer is depending on their nationality. Results clearly show that Facebook activities by European representatives vary according to their nationalities, probably because of differences in political cultures. Our analysis shows that the vast majority of Spanish MEPs uses Facebook primarily as a one-way communication tool, while Danish MEPs and citizens have a more dialogue-oriented approach to it.

In this sense, our findings on Spanish MEPs confirm previous research: political actors mainly use Facebook as a platform to advertise themselves (Muñiz et al., 2016; Vesnic-Alujevic, 2016) and to publish updates on different issues for public discussion (Camaj; Santana, 2015), but they rarely engage in conversations with citizens (Fenoll; Cano-Orón, 2017; Koc-Michalska et al., 2016). In other words, communicative interaction between Spanish MEPs and citizens is rather infrequent, with only a minority of engaged representatives showing inclination towards dialogue with their Facebook followers.

In contrast, Danish MEPs use Facebook in a significantly more dialogue-oriented way. They do not only publish updates periodically, but, more importantly, these political posts often lead to conversations. Most Danish MEPs also take active part in these discussions. Both the extensive Facebook use by Danish MEPs and their willingness to establish discussion with citizens echo previous research on Scandinavian political actors' approach to social media (Sørensen, 2016a; 2016b; Larsson; Kalsnes, 2014).

Our results point to an interesting relationship of political orientations with social media use, so that left-wing ideology is associated with a more intensive presence and activity on Facebook, maybe as a result of the historic role played by left-wing parties in encouraging citizen participation (Janssen; Kies, 2005). Still, this relationship will have to be further explored through more refined statistical analysis and bigger samples.

Finally, this study's last contribution is the confirmation of significant differences in how political actors from different nationalities and political cultures use social media (RQ3). Thus, our findings clearly suggest that the different political cultures in the Danish and Spanish case influence their respective attitudes towards the use of Facebook. On the one hand, Danish MEPs seem to be conscious about the importance of conversations for democracy: that is why they do not only publish updates, but also involve themselves in discussions with citizens. Most Spanish MEPs, on the other hand, exhibit a more reluctant attitude towards interacting with citizens and limit their Facebook use to agenda setting through content publication.

\section{Conclusion}

The Brexit crisis has recently reminded all of us of the EU's political legitimacy problems, and the well-known problem of the 'democratic deficit' (Weiler; Haltern; Mayer, 1995). Although the European Parliament has gained influence over the years, and its decisions have wide-ranging effects for European citizens, it is still far behind national parliaments when it comes to media coverage and the ability to connect with people's ideological identifications (Seoane-Pérez, 2013). Thus, so far it has proven very hard to make European citizens interested in what is going on in the European Parliament, as shown in the limited turnout in the European Parliament elections. For example, in the 2014 elections, the turnout was less than 43 percent, a significantly lower number compared to national elections (The European Parliament, 2014). In the 2019 European Parliament election, participation increased for the first time in 20 years (reaching 50 percent), but it is still significantly below the turnout in national elections and lower than the turnout during the 1970ies and 1980ies.

In this context, it is an interesting question if social media in general and Facebook in particular could help connect citizens with their representatives in the European Parliament, serving as a venue for discussing public issues of interest 
across national borders. Would it be possible to create more legitimacy around decisions taken in the European Parliament via a livelier debate on Facebook? Do we see the contours of an emerging European public sphere in the Facebook pages of MEPs?

The results reported in this paper suggest some interesting potentiality. As shown, Facebook is today used for political conversations between parliamentarians and citizens, especially in the case of Danish MEPs, but also in that of some of the Spanish MEPs, who clearly also conceive it as a tool for fostering genuine political discussions. There is, in other words, some basic ground for developing a more vibrant European public sphere using Facebook and other social media. Since our approach was basically quantitative, future works will have to offer more fruitful analyses of what kind of thematic issues are published by MEPs, what type of content attracts the most attention, and what the basic features of conversations that take place between them and citizens are (probably through qualitative approaches).

Our study clearly shows that there is room for improvements, and that social media features can be more widely adopted and better used by European representatives. Given the fact that most Europeans use Facebook on a daily basis and that most MEPs have a Facebook page, MEPs could do much more to foster political conversations with citizens, and use social media in a more dialogue-oriented way. One could imagine MEPs experimenting much more with, for example, weekly scheduled hours on Facebook where they answer questions and engage in debates with citizens on ongoing issues.

However, our study shows that too many MEPs still only use Facebook as a one-way communication channel, thus failing to implicate their followers in discussion. This is a shame because citizens can indeed be involved in conversations, as the case of Jens Rohde shows. Yet we also know from previous studies that this requires a lot of energy and effort from the MEPs (Sørensen, 2016b).

In this sense, our conclusions are in line with those of previous studies about how political actors use online tools across Europe:

"features are used due to their perceived utility for meeting campaigning objectives (...). However, this stifles innovation and the shift towards a more interactive paradigm of campaign communication that may have a positive impact on the engagement of citizens in party politics" (Koc-Michalska et al., 2016, p. 346).

A good deal of the MEPs analyzed in this study seem to share this logic, since they were relatively inactive during a regular non-electoral period.

In any case, the infrastructure for a more vibrant European public sphere seems to be in place, ready to be fully adopted. Unfortunately, infrastructure is not enough. Without a real interest and a true willingness from MEPs to engage citizens in the work they do in the $E P$, conversations will not take place. In this sense, a main obstacle for realizing the potentiality of Facebook seems to be that most MEPs do not really invest enough time in addressing issues raised by citizens in their comments. Here, political cultures seem to play a main role in influencing MEPs' answering behavior. Our study has revealed significant national differences between Danish and Spanish MEPs' approach to Facebook. Future research will have to corroborate these national differences between political cultures, extending the analysis to social media use of MEPs elected from other European countries.

\section{Notes}

1. One of the best known texts on democracy in Denmark is Hal Koch's book 'What is democracy?', written just after the Second World War. A core idea in Koch's understanding of democracy is that

“... democracy is not determined by voting, but by conversation, negotiation, by mutual respect and understanding and by the resulting emerging sense of the common interest" (Koch, 1991 [1945], p. 23).

This book is still widely read, and in 2008 it was made part of the official "democracy canon," i.e. selected as one of 35 important events, philosophical ideas, and political texts that have influenced and helped develop democratic ideals in Denmark (Udvalget til udarbejdelse af en demokratikanon og Undervisningsministeriet, 2008).

2. Parties were coded in the following way: in the Danish case:

- Socialist People's Party, Social Democratic Party, People Movement against the EU, and Danish Social-Liberal Party were coded as left-wing parties.

- Conservative People's Party, Danish People's Party, and Liberals were treated as right.

In the Spanish case:

- Izquierda Unida, Podemos, Partido Socialista Obrero Español, Partit dels Socialistes de Catalunya, Equo, Eh Bildu, Esquerra Republicana de Catalunya, Alternativa Galega de Esquerda en Europa, and Iniciativa per Catalunya Verds were coded as left.

- Partido Popular, Ciudadanos, Unión Progreso y Democracia, Convergència Democràtica de Catalunya, and Unió Democràtica de Catalunya were considered right parties.

The MEPs treated as independent were Rikke Karlsson, Beatriz Becerra Basterrechea, and Enrique Calvet Chambón. 
3. Jens Rohde is clearly an outlier (Figures 6 and 7). That is why we chose to corroborate our results regarding national differences taking him out of the calculations, in order to prevent the strong influence of his case on the general descriptive measures of our distribution.

\section{References}

AIMC (2017). Navegantes en la Red. Infografía 20a․ Madrid: Asociación para la Investigación de Medios de Comunicación.

https://www.aimc.es/otros-estudios-trabajos/navegantes-la-red/infografia-resumen-20o-navegantes-la-red

Alonso-Muñoz, Laura; Casero-Ripollés, Andreu (2018). “Communication of European populist leaders on Twitter: Agenda setting and the 'more is less' effect". El profesional de la información, v. 27, n. 6, pp. 1193-1202.

https://doi.org/10.3145/epi.2018.nov.03

Bossetta, Michael (2018). "The digital architectures of social media: Comparing political campaigning on Facebook, Twitter, Instagram, and Snapchat in the 2016 U.S. election". Journalism \& mass communication quarterly, v. 95, n. 2, pp. 471-496.

https://doi.org/10.1177/1077699018763307

Bouza-García, Luis; Tuñón-Navarro, Jorge (2018). “Personalización, distribución, impacto y recepción en Twitter del discurso de Macron ante el Parlamento Europeo el 17/04/18". El profesional de la información, v. 27, n. 6, pp. 1239-1247. https://doi.org/10.3145/epi.2018.nov.07

Camaj, Lindita; Santana, Arthur D. (2015). "Political deliberation on Facebook: Exploring the relevance of moderator's technical role and political ideology". Journal of information, technology \& politics, v. 12, n. 4, pp. 325-341.

https://doi.org/10.1080/19331681.2015.1100224

Cardenal, Ana S. (2013). "Why mobilize support online? The paradox of party behaviour online". Party politics, v. 19, n. 1, pp. 83-103.

https://doi.org/10.1177/1354068810395059

Casero-Ripollés, Andreu; Feenstra, Ramón A.; Tormey, Simon (2016). “Old and new media logics in an electoral campaign: The case of Podemos and the two-way street mediatization of politics". The international journal of press/politics, v. 21, n. 3, pp. 378-397.

https://doi.org/10.1177/1940161216645340

CIS (2016). Estudio CIS n. 3126: Postelectoral elecciones generales 2015. Centro de Investigaciones Sociológicas.

http://www.cis.es/cis/export/sites/default/-Archivos/Marginales/3120_3139/3126/Ft3126.pdf

CIS (2017). Estudio CIS n. 3168: Barómetro de febrero 2017. Centro de Investigaciones Sociológicas. http://www.cis.es/cis/export/sites/default/-Archivos/Marginales/3160_3179/3168/esmar3168mar.html

Dader, José-Luis (2009). “Ciberpolítica en los websites de partidos políticos: la experiencia de las elecciones de 2008 en España ante las tendencias transnacionales". Revista de sociologia e politica, v. 17, n. 34, pp. 45-62.

https://doi.org/10.1590/s0104-44782009000300005

Delgado-Sotillos, Irene; López-Nieto, Lourdes (2008). Comportamiento político y sociología electoral. Madrid: UNED. ISBN: 9788436255812

Dewey, John (1991 [1927]). The public and its problems. Athens, Ohio: Swallow Press/Ohio University Press. ISBN: 978 0804002547

Di-Bonito, Ilaria (2014). "El uso de Facebook durante las campañas electorales. Reflexiones sobre las elecciones catalanas de 2010 y 2012". Revista de la Asociación Española de Investigación de la Comunicación, v. 1, n. 1, pp. 26-34.

http://www.revistaeic.eu/index.php/raeic/article/view/17

Ekman, Mattias; Widholm, Andreas (2017). "Political communication in an age of visual connectivity: Exploring Instagram practices among Swedish politicians". Northern lights, v. 15, n. 1, pp. 15-32.

https://doi.org/10.1386/nl.15.1.15_1

Fenoll, Vicente; Cano-Orón, Lorena (2017). “Citizen engagement on Spanish political parties' Facebook pages: Analysis of the 2015 electoral campaign comments". Communication \& society, v. 30, n. 4, pp. 131-145.

https://www.unav.edu/publicaciones/revistas/index.php/communication-and-society/article/view/35763

https://doi.org/10.15581/003.30.3.131-147

Fernandes, Juliana; Giurcanu, Magda; Bowers, Kevin W.; Neely, Jeffrey C. (2010). "The writing on the wall: A content analysis of college students' Facebook groups for the 2008 presidential election". Mass communication and society, v. 13, n. 5, pp. 653-675.

https://doi.org/10.1080/15205436.2010.516865 
Filiminov, Kirill; Russmann, Uta; Svensson, Jakob (2016). "Picturing the party: Instagram and party campaigning in the 2014 Swedish elections". Social media + society, v. 2, n. 3, pp. 1-11.

https://doi.org/10.1177/2056305116662179

Flyvbjerg, Bent (2006). "Five misunderstandings about case-study research". Qualitative inquiry, v. 12, n. 2, pp. $219-245$. https://doi.org/10.1177/1077800405284363

Føllesdal, Andreas; Hix, Simon (2006). "Why there is a democratic deficit in the EU: A response to Majone and Moravcsik". Journal of common market studies, v. 44, n. 3, pp. 533-562.

https://doi.org/10.1111/j.1468-5965.2006.00650.x

Gámir-Ríos, José (2016). “Blogs, Facebook y Twitter en las elecciones generales de 2011. Estudio cuantitativo del uso de la web 2.0 por parte de los cabezas de lista del PP y del PSOE”. Dígitos. Revista de comunicación digital, n. 2, pp. $101-120$. https://revistadigitos.com/index.php/digitos/article/view/53

Habermas, Jürgen (1989 [1962]). The structural transformation of the public sphere: An inquiry into a category of bourgeois society. Cambridge: Polity. ISBN: 9780745602745

Habermas, Jürgen (1974). "The public sphere: An encyclopedia article (1964)”. New German critique, v. 3, pp. 49-55. https://unige.ch/sciences-societe/socio/files/2914/0533/6073/Habermas_1974.pdf

Hallin, Daniel C.; Mancini, Paolo (2004). Comparing media systems: Three models of media and politics. Cambridge: Cambridge University Press. ISBN: 9780521543088

Internet World Stats (2017). Internet in Europe stats: Internet user statistics \& 2017 population for the 53 European countries and regions.

http://www.internetworldstats.com/europa.htm

Janssen, Davy; Kies, Raphaël (2005). “Online forums and deliberative democracy”. Acta politica, v. 40, n. 3, pp. 317-335. https://doi.org/10.1057/palgrave.ap.5500115

Koch, Hal (1991 [1945]). Hvad er demokrati? [What is democracy?]. Copenhagen: Gyldendal. ISBN: 9788700058033

Koc-Michalska, Karolina; Lilleker, Darren G.; Smith, Alison; Weissmann, Daniel (2016). "The normalization of online campaigning in the web 2.0 era". European journal of communication, v. 31, n. 3, pp. 331-350.

https://doi.org/10.1177/0267323116647236

Larsson, Anders O.; Kalsnes, Bente (2014). "Of course we are on Facebook: Use and non-use of social media among Swedish and Norwegian politicians". European journal of communication, v. 29, n. 6, pp. 653-667.

https://doi.org/10.1177/0267323114531383

Lilleker, Darren G.; Jackson, Nigel A. (2010). "Towards a more participatory style of election campaigning? The impact of web 2.0 on the UK 2010 general election". Policy \& internet, v. 2, n. 3, pp. 69-98.

https://doi.org/10.2202/1944-2866.1064

Lilleker, Darren G.; Koc-Michalska, Karolina (2014). “Online election campaigning: Exploring supply and demand during the France 2012 presidential election". In: Solo, Ashu. Political campaigning in the information age, pp. 287-304. Hershey, PA: IGI Global. ISBN: 9781466660625

López-García, Guillermo (2016). “'New’ vs 'old’ leaderships: The campaign of Spanish general elections 2015 on Twitter". Communication \& society, v. 29, n. 3, pp. 149-168.

https://www.unav.edu/publicaciones/revistas/index.php/communication-and-society/article/view/35829

https://doi.org/10.15581/003.29.3.149-168

López-García, Guillermo; Gámir-Ríos, José V.; García-Ull, Francisco J.; Llorca-Abad, Germán; Cano-Orón, Lorena; González-Esteban, José-Luis (2015). “El debate sobre Europa en Twitter. Discursos y estrategias de los candidatos de las elecciones al Parlamento Europeo de 2014 en España”. Revista de estudios políticos, n. 170, pp. 213-246.

https://doi.org/10.18042/cepc/rep.170.07

López-Meri, Amparo; Marcos-García, Silvia; Casero-Ripollés, Andreu (2017). “What do politicians do on Twitter? Functions and communication strategies in the Spanish electoral campaign of 2016". El profesional de la información, v. 26, n. 5, pp. 795-804.

https://doi.org/10.3145/epi.2017.sep.02

Muñiz, Carlos; Campos-Domínguez; Eva; Saldierna, Ana-Rosa; Dader, José-Luis (2019). “Engagement of politicians and citizens in the cyber campaign on Facebook: A comparative analysis between Mexico and Spain". Contemporary social science, v. 14, n. 1, pp. 102-113.

https://doi.org/10.1080/21582041.2017.1367832 
Muñiz, Carlos; Dader, José-Luis; Téllez, Nilsa M.; Salazar, Alondra (2016). “¿Están los políticos políticamente comprometidos? Análisis del compromiso político 2.0 desarrollado por los candidatos a través de Facebook". Cuadernos.info, v. 39, pp. 135-150.

https://doi.org/10.7764/cdi.39.970

Robertson, Scott P.; Vatrapu, Ravi K.; Medina, Richard (2010). “Off the wall political discourse: Facebook use in the 2008 U.S. presidential elections". Information polity, v. 15, n. 1-2, pp. 11-31.

https://doi.org/10.3233/IP-2010-0196

Ross, Karen; Fountaine, Susan; Comrie, Margie (2015). "Facing up to Facebook: Politicians, publics and the social media(ted) turn in New Zealand". Media, culture \& society, v. 37, n. 2, pp. 251-269.

https://doi.org/10.1177/0163443714557983

Sampietro, Agnese; Valera-Ordaz, Lidia (2015). “Emotional politics on Facebook: An exploratory study of Podemos' discourse during the European election campaign 2014". Recerca. Revista de pensament i anàlisi, n. 17, pp. 61-83.

https://doi.org/10.6035/Recerca.2015.17.4

Schudson, Michael (1997). "Why conversation is not the soul of democracy". Critical studies in mass communication, v. 14, n. 4, pp. 297-309.

https://doi.org/10.1080/15295039709367020

Seoane-Pérez, Francisco (2013). Political communication in Europe. The cultural and structural limits of the European public sphere. UK: Palgrave Macmillan. ISBN: 9781137305138

Shah, Dhavan V. (2016). "Conversation is the soul of democracy: Expression effects, communication mediation, and digital media". Communication and the public, v. 1, n. 1, pp. 12-18.

https://doi.org/10.1177/2057047316628310

Sørensen, Mads P. (2016a). "Members of parliament on Facebook: Towards an understanding of the pros and cons of online political conversations". In: Nielsen, Henrik-Kaare; Fiig, Christina; Loftager, Jørn; Olesen, Thomas; Løhman-Stephensen, Jan; Sørensen, Mads P. (eds.). The democratic public sphere: Current challenges and prospects, pp. 197-226. Aarhus, Denmark: Aarhus University Press. ISBN: 8771841040

Sørensen, Mads P. (2016b). “Political conversations on Facebook: The participation of politicians and citizens”. Media, culture and society", v. 38, n. 5, pp. 664-685.

https://doi.org/10.1177/0163443715620924

Sudulich, Maria-Laura (2013). "Do ethos, ideology, country and electoral strength make a difference in cyberspace? Testing an explanatory model of parties' websites". In: Nixon, Paul; Rawal, Rajash; Mercea, Dan (eds.) Politics and the Internet in comparative context: Views from the cloud. London \& New York: Routledge, pp. 75-94. ISBN: 9781135104023 https://doi.org/10.4324/9780203798331

Sweetser, Kaye D.; Lariscy, Ruthann-Weaver (2008). “Candidates make good friends: An analysis of candidates' uses of Facebook". International journal of strategic communication, v. 2, n. 3, pp. 175-198.

https://doi.org/10.1080/15531180802178687

Teorell, Jan; Torcal, Mariano; Montero, José-Ramón (2007). “Political participation. Mapping the terrain”. In: Van-Deth, Jan; Montero, José-Ramón; Westholm, Anders. Citizenship and European democracies: A comparative perspective. London \& New York: Routledge, pp. 334-357. ISBN: 9780203965757

The Danish Agency for Culture and Palaces (2017). Media development in Denmark 2017: Summary and discourse. https://slks.dk/fileadmin/user_upload/dokumenter/medier/Mediernes_udvikling/2017/Overblik_og_perspektivering/ EN_Overblik_og_perspektivering_2017.pdf

The European Parliament (2014). Results of the 2014 European elections. http://www.europarl.europa.eu/elections2014-results/en/turnout.html

The European Parliament (2019). Resultados de las elecciones europeas de 2019. https://resultados-elecciones.eu/participacion

Torcal, Mariano; Montero, José-Ramón; Teorell, Jan (2006). “La participación política en España: modos y niveles en perspectiva comparada". Revista de estudios políticos, n. 132, pp. 7-14.

https://recyt.fecyt.es/index.php/RevEsPol/article/view/45507

https://doi.org/10.18042/45507

Túñez, Miguel; Sixto, José (2011). “Redes sociales, política y compromiso 2.0: La comunicación de los diputados españoles en Facebook". Revista latina de comunicación social, v. 66, pp. 212-240.

https://doi.org/10.4185/RLCS-66-2011-930-210-246 
Udvalget til udarbejdelse af en demokratikanon og Undervisningsministeriet (2008) Demokratikanon. Ministry of Education.

http://static.uvm.dk/Publikationer/2008/demokratikanon/helepubl.pdf

Valera-Ordaz, Lidia (2017). “Comparación del valor democrático de las discusiones de Facebook entre perfiles de candidatos políticos españoles a las elecciones generales de 2011". Revista internacional de sociología, v. 75, n. 1, e052. https://doi.org/10.3989/ris.2017.75.1.15.119

Valera-Ordaz, Lidia (2019). "Liberal individualist, communitarian, or deliberative? Analyzing political discussion on Facebook based on three notions of democracy". International journal of communication, v. 13, pp. 1056-1076. https://ijoc.org/index.php/ijoc/article/view/8309/2584

Vesnic-Alujevic, Lucia (2012). "Political participation and web 2.0 in Europe: A case study of Facebook". Public relations review, v. 38, n. 3, pp. 466-470.

https://doi.org/10.1016/j.pubrev.2012.01.010

Vesnic-Alujevic, Lucia (2013). Members of European Parliament online: The use of social media in political marketing. Center for European Studies.

https://www.martenscentre.eu/sites/default/files/publication-files/political-marketing-and-social-media.pdf

Vesnic-Alujevic, Lucia (2016). “European elections and Facebook: Political advertising and deliberation?”. In: Dezelan, Tomaz; Vobic, Igor. (R)evolutionizing political communication through social media. Hershey PA: Information Science Reference/IGI Global, pp. 191-209. ISBN: 9781466698796

https://www.igi-global.com/gateway/chapter/145986

Weiler, Joseph H. H.; Haltern, Ulrich R.; Mayer, Franz C. (1995). "European democracy and its critique”. West European politics, v. 18, n. 3, pp. 4-39.

https://doi.org/10.1080/01402389508425089

Wright, Scott (2011). "Politics as usual? Revolution, normalization and a new agenda for online deliberation". New media \& society, v. 14, n. 2, pp. 244-261.

https://doi.org/10.1177/1461444811410679

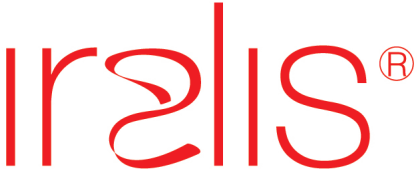

International Registry for Authors: Links to Identify Scientists

es:

- una guía para los autores hispanos para que firmen sus trabajos en el formato internacional usual

- una base de datos que registra las variantes de firma usadas por cada autor en diferentes épocas

- un buscador que usa automáticamente todas las variantes registradas

¡Ni un día más sin decidir tu firma!

Inscríbete en http://iralis.org

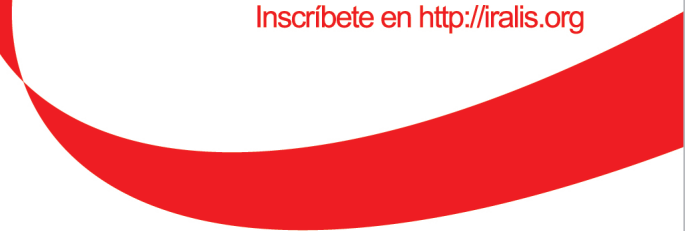

\section{El formato de ffrma internacional}

Con el apoyo de:

El profesional de la información

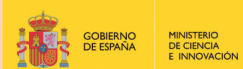

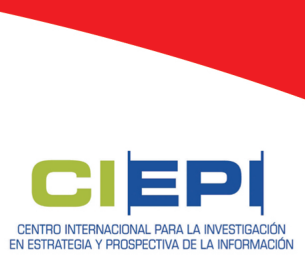

